Vol. 1 No. 2 Desember 2021, e-ISSN : 2807-8659 | p-ISSN : 2807-8829

\title{
PENERAPAN STRATEGI MODELLING THE WAY UNTUK MENINGKATKAN KEMAMPUAN SHALAT WAJIB SISWA
}

\author{
ASNGADI \\ SDN Tri Mulya Agung \\ e-mail: asngadi7@gmail.com
}

\begin{abstract}
ABSTRAK
Penelitian ini bertujuan mendeskripsikan untuk meningkatkan kemampuan melakukan sholat wajib melalui strategi modelling the way pada siswa kelas IV SDN Tri Mulya Agung Semester genap tahun pelajaran 2018/2019 dengan jumlah siswa 23 siswa. Metode yang digunakan dalam penelitian ini adalah metode penelitian tindakan kelas, pengumpulan data melalui observasi, wawancara dan tes atau penugasan, sedangkan analisis data dilakukan dengan model interaktif. Sedangkan aktifitas dilakukan dalam bentuk interaktif dengan proses pengumpulan data sebagai proses siklus. Hasil penelitian menunjukkan bahwa melalui strategi modelling the way dapat meningkatkan kemampuan melakukan sholat wajib pada siswa kelas IV SDN Tri Mulya Agung Semester genap tahun pelajaran 2018/2019. Aktivitas belajar dari siklus I ke siklus II terdapat peningkatan: aspek membaca rukun sholat (nilai rata-rata meningkat 1,1; persentase naik 21,8\%; dari kategori baik menjadi amat baik), aspek membaca syarat sholat (nilai rata-rata naik 0,7; prosentase naik 14,8\%; dari kategori baik menjadi amat baik); aspek membaca hal yang membatalkan sholat (nilai rata-rata meningkat 0,7 ; persentase naik $15,7 \%$; dari kategori baik menjadi amat baik), dan aspek praktek sholat (nilai rata-rata naik 0,9 ; prosentase naik 18,3\%; dari kategori baik menjadi amat baik). Hasil belajar siswa dari kondisi awal ke siklus II mengalami peningkatan, yaitu dari 7 siswa (30\%) yang mendapat nilai tuntas menjadi 23 siswa (100\%). Terjadi peningkatan sebanyak 16 siswa (70\%) dan nilai rata-rata kelas dari 60,2 menjadi 85,0, meningkat sebesar 24,8.
\end{abstract}

Kata kunci : Meningkatkan, kemampuan melakukan sholat wajib, strategi modelling the way.

ABSTRACT

This research aims to improve the ability to perform mandatory prayers through modeling the way strategies in students of grade IV SDN Tri Mulya Agung Semester even the 2018/2019 school year with the number of students 23 students. The methods used in this study are classaction research methods, data collection through observation, interviews and tests or assignments, while data analysis is done with interactive models. While the activity is carried out in interactive form with the process of collecting data as a cyclical process. The results showed that through modeling strategies the way can improve the ability to perform mandatory prayers in students of grade IV SDN Tri Mulya Agung Semester even the year of study 2018/2019. Learning activities from cycle I to cycle II there is an increase: aspects of reading the pillars of prayer (average value increases 1.1; percentages rise $21.8 \%$; from good category to very good), aspect of reading prayer conditions (average value up 0.7; percentage up 14.8\%; from good category to very good); aspects of reading things that cancel prayers (average value increased 0.7 ; percentage rose $15.7 \%$; from good category to very good), and aspect of prayer practice (average value rose 0.9 ; percentage rose $18.3 \%$; from good category to very good). Student learning outcomes from the initial condition to cycle II increased, from 7 students $(30 \%)$ who got completed grades to 23 students (100\%). There was an increase of 16 students (70\%) and the grade point average from 60.2 to 85.0, an increase of 24.8.

Keywords: Improve, the ability to perform mandatory prayers, modeling strategies the way.

\section{PENDAHULUAN}

Kemampuan melaksanakan sholat dengan baik dan benar merupakan salah satu kemampuan yang harus dimiliki oleh siswa sebagai hasil belajar pada materi sholat dikelas IV $\mathrm{SD}$, oleh karena itu pembelajaran sholat khususnya pada kemampuan praktek menjadi perhatian guru dan siswa. Pemilihan strategi modeling the way yang akan membantu siswa dan guru 
dalam mewujudkan tujuan yang ingin dicapai, sesuai dengan pendapat Menurut Zaini, (2008: 76) strategi Modelling The Way memberi kesempatan kepada peserta didik untuk mempraktekkan keterampilan spesifik yang di pelajari dikelas melalui demonstrasi.

Dalam Anegawati, (2016) modelling adalah hal yang menjadi model. Berdasarkan defenisi tersebut, dalam penelitian ini model adalah sebagai contoh. Contoh yang dimaksudkan adalah pilihan kata (diksi), pelafalan, intonasi, dan ketepatan isi untuk dicontoh oleh siswa. Artinya, ada pesan yang akan disampaikan dan guru memberikan contoh cara menyampaikan pesan tersebut kepada pihak lain. Misalnya pesan dari ayah kepada kakak untuk di sampaikan kepada adikadiknya dengan tepat tampa mengubah pesan tersebut. Teknik pemodelan atau modelling the way adalah suatu bagian dari metode mengajar dengan cara mengadakan latihan yang berulang-ulang sampai siswa mahir melakukan apa yang telah di pelajari. Teknik ini berlandaskan bahwa pembelajaran yang dilakukan secara berulang-ulang menghasilkan lebih maksimal jika dibandingkan dengan pekerjaan yang dilakukan hanya sekalisekali.

Berdasarkan kompetensi dasar yang tercantum pada silabus mata pelajaran PAI di tingkat sekolah dasar pada kelas 4, menuntut kecakapan melakukan gerakan sholat wajib dengan baik dan benar, Nanum pada kenyataannya kebanyakan siswa kelas 4 belum mampu melakukan gerakan sholat dengan baik dan benar. Hal ini terlihat dari hasil pengamatan praktek sholat yang dilakukan di kelas 4 SDN Tri Mulya Agung terlihat bahwa masih banyak siswa yang belum mampu melakukan gerakan-gerakan sholat dengan baik dan benar, terlebih pada kenyataannya, dari pengalaman selama mengajar, dapat dicermati, bahwa siswa yang lulus dari sekolah dasar bahkan sampai dijenjang SMA pun, masih banyak yang belum mampu melakukan gerakan sholat dengan baik dan benar, Padahal kebanyakan dari mereka adalah beragama Islam, dimana sholat merupakan kewajiban yang harus dilakukan oleh setiap pemeluknya. Hal ini termaktub dalam alqur'an dalam surah Al-Baqarah ayat 43

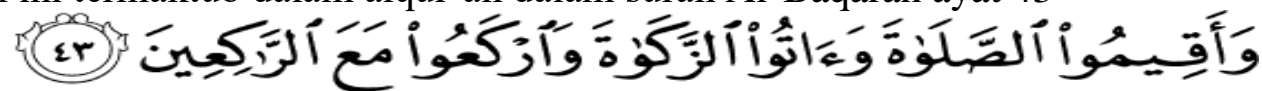

“(43) Dan dirikanlah shalat, tunaikanlah zakat dan ruku'lah beserta orang-orang yang ruku( Al-baqarah : 43)"

Kesenjangan-kesenjangan inilah yang membawa peneliti, untuk melakukan penelitian ini, guna meningkatkan kemampuan dalam melakukan gerakan sholat wajib dengan baik dan benar pada siswa kelas 4 SDN Tri Mulya Agung, Tahun pelajaran 2018/2019

\section{METODE PENELITIAN}

Pendekatan penelitian yang digunakan adalah penelitian tindakan kelas (PTK). Menurut Kunandar (2011) Penelitian tindakan kelas termasuk penelitian kualitatif meskipun data yang dikumpulkan bisa saja bersifat kuantitatif, dimana uraiannya bersikap deskriptif dalam bentuk kata-kata, peneliti merupakan instrumen pertama dalam pengumpulan data, proses sama pentingnya dengan produk.

Menurut Arikunto (2015), PTK dilaksanakan melalui pengkajian berdaur yang terdiri dari 4 (empat) tahap, yaitu merencanakan, melakukan tindakan, mengamati, dan melakukan refleksi, seperti pada Gambar 1

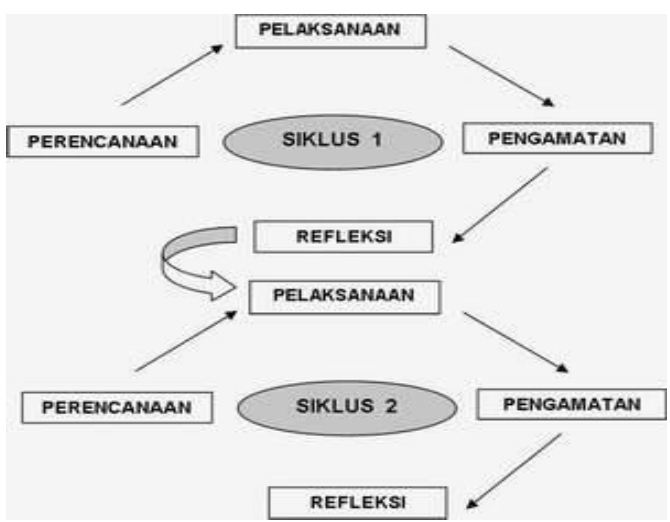

Gambar 1. Tahap-tahap PTK 


\section{Siklus I}

Pertama, tahap perencanaan. Kegiatan yang dilakukan adalah menentukan indikator untuk mengukur pencapaian pemecahan masalah, melakukan pembicaraan dengan Kepala Sekolah dan beberapa orang guru untuk menentukan pembimbing serta observer, membuat rencana pelaksanaan pembelajaran (RPP) yang mencakup langkah-langkah yang akan dilaksanakan oleh peneliti dan apa yang dilakukan oleh siswa, menyiapkan instrumen evaluasi dan observasi, sarana, fasilitas, dan sumber belajar yang diperlukan di dalam kelas. Kedua, tahap pelaksanaan tindakan. Kegiatan yang dilakukan adalah membagi siswa dalam 4 kelompok, yang terdiri 6 orang, menyajikan materi pelajaran, menggunakan strategi modelling the way tanpa bimbingan guru, bersama siswa melakukan penguatan dan kesimpulan, memberikan penghargaan kelompok, dan observer melakukan pengamatan. Ketiga, tahap observasi. Kegiatan ini dilakukan oleh observer (peneliti) bersamaan dengan pelaksanaan tindakan. Observer melakukan pengamatan terhadap situasi pembelajaran, keaktifan siswa, dan kemampuan siswa dalam demonstrasi. Keempat, tahap refleksi. Kegiatan yang dilakukan adalah mendiskusikan hasil observasi dan hasil belajar siswa. Khususnya hasil belajar siswa, dibandingkan dengan indikator keberhasilan.

\section{Siklus II}

Pertama, tahap perencanaan, meliputi: membuat rencana pembelajaran berdasarkan hasil refleksi pada siklus pertama, menyiapkan media dan sarana, serta menyiapkan instrument observasi. Kedua, tahap pelaksanaan yaitu guru melaksanakan pembelajaran berdasarkan rencana pembelajaran hasil refleksi pada siklus pertama. Ketiga, tahap pengamatan, yaitu peneliti melakukan pengamatan terhadap aktifitas pembelajaran. Keempat, tahap relfleksi yaitu peneliti melakukan refleksi terhadap pelaksanaan siklus kedua, menganalisis, serta membuat kesimpulan atas pelaksanaan pembelajaran berdasarkan tindakan.

\section{HASIL DAN PEMBAHASAN}

Penelitian Tindakan kelas ini dilaksanakan pada tanggal 11 April 2019 sebagai siklus I dan tanggal 18 April 2019 sebagai silkus II. Subyek penelitian adalah kelas IV SDN Tri Mulya AgungKecamatan Lalan Kabupaten Musi Banyuasin tahun pelajaran 2018/2019 yang berjumlah 23 orang.

\section{Hasil}

Hasil aktivitas belajar siswa materi mempraktikkan sholat wajib pada Siklus I dapat dilihat pada tabel dan gambar grafik berikut.

Tabel 1. Nilai Praktik Sholat Wajib Siklus I

\begin{tabular}{|c|l|c|c|c|c|}
\hline No & \multicolumn{1}{|c|}{ Aspek-aspek } & $\begin{array}{c}\text { Jumlah } \\
\text { Skor }\end{array}$ & $\begin{array}{c}\text { Rata- } \\
\text { rata }\end{array}$ & Persentase & Kategori \\
\hline 1 & Melafalkan bacaan-bacaan sholat wajib & 78 & 3,4 & 67,8 & Baik \\
\hline 2 & $\begin{array}{l}\text { Mempraktikkan gerakan-gerakan dalam } \\
\text { sholat wajib }\end{array}$ & 85 & 3,7 & 73,9 & Baik \\
\hline 3 & $\begin{array}{l}\text { Mem Praktikkan keserasian antara } \\
\text { bacaan dan gerakan sholat wajib }\end{array}$ & 82 & 3,6 & 71,3 & Baik \\
\hline
\end{tabular}




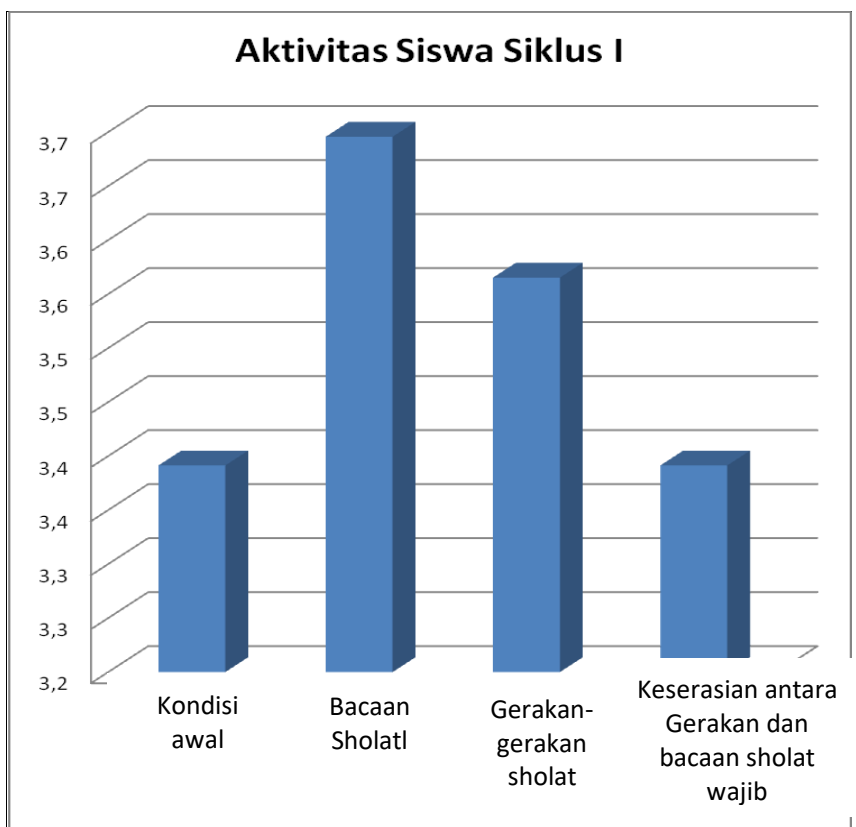

Gambar 2. Grafik Aktivitas Belajar Siklus I

Berdasarkan tabel dan gambar grafik diatas tentang hasil pengamatan aktivitas belajar praktik sholat wajib siklus I pada siswa kelas IV SDN Tri Mulya Agung semester genap tahun pelajaran 2018/2019, yang meliputi aspek 1) Melafalkan bacaan-bacaan sholat wajib; 2) Mempraktikkan gerakan-gerakan sholat wajib; 3) Mempraktikkan keserasian antara gerakan dan bacaan sholat wajib, diperoleh skor rata-rata aktivitas kategori baik.

Hasil praktik siswa pada siklus I dapat dilihat pada tabel dan gambar grafik berikut.

Tabel 2. Nilai Praktik sholat wajib Siklus I

\begin{tabular}{|c|c|c|}
\hline No & Uraian & Nilai Praktik \\
\hline 1 & Nilai terendah & 60 \\
\hline 2 & Nilai tertinggi & 100 \\
\hline 3 & Nilai rerata & $\mathbf{7 5 , 2}$ \\
\hline 4 & Rentang nilai & 40 \\
\hline
\end{tabular}

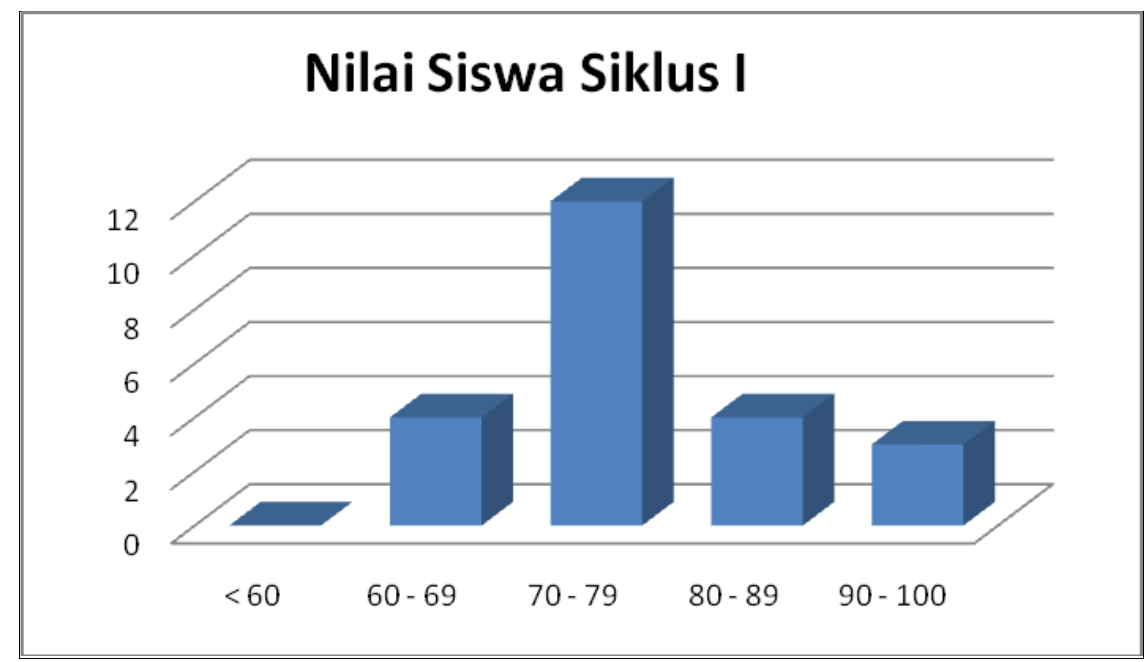

Gambar 3. Grafik Nilai praktik sholat wajib Siklus I 


\section{nilai ketuntasan Siklus I}

tuntas $\square$ belum tuntas

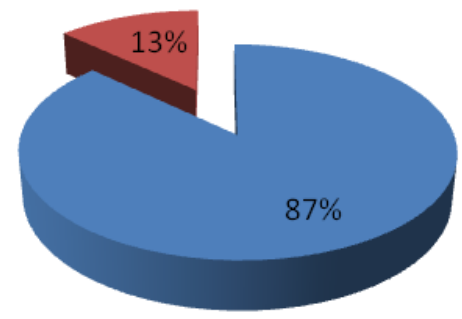

\section{Gambar 4. Grafik Nilai Ketuntasan Belajar Siklus I}

Berdasarkan Tabel dan Gambar grafik diatas diketahui hasil nilai praktik sholat wajib siklus I pada siswa kelas IV SDN Tri Mulya Agung tahun pelajaran 2018/2019 masih ada 3 siswa (13\%) yang dinyatakan belum tuntas, dengan nilai siswa terendah 60, nilai tertinggi 100 dan nilai rata kelas 75,2 .

Hasil praktik shalat siswa pada Siklus II dapat dilihat pada tabel dan gambar grafik berikut.

Tabel 3. Nilai Praktik Shalat Siklus II

\begin{tabular}{|c|l|c|c|c|c|}
\hline No & \multicolumn{1}{|c|}{ Aspek-aspek } & $\begin{array}{c}\text { Jumlah } \\
\text { Skor }\end{array}$ & $\begin{array}{c}\text { Rata- } \\
\text { rata }\end{array}$ & Persentase & Kategori \\
\hline 1 & $\begin{array}{l}\text { Melafalkan bacaan-bacaan } \\
\text { sholat wajib }\end{array}$ & 103 & 4,5 & 89,6 & Amat baik \\
\hline 2 & $\begin{array}{l}\text { Mempraktikkan gerakan- } \\
\text { gerakan sholat wajib }\end{array}$ & 102 & 4,4 & 88,7 & Amat baik \\
\hline 3 & $\begin{array}{l}\text { Mempraktikkan keserasian } \\
\text { antara bacaan dan gerakan } \\
\text { sholat wajib }\end{array}$ & 100 & 4,3 & 87,0 & Amat baik \\
\hline
\end{tabular}

Berdasarkan Tabel diatas diketahui hasil praktik shalat siswa kelas IV SDN Tri Mulya Agung tahun pelajaran 2018/2019, yang meliputi aspek:

1) Melafalkan bacaan-bacaan shalat;

2) Mempraktikkan gerakan-gerakan shalat wajib;

3) Mempraktikkan keserasian antara bacaan dan gerakan shalat wajib.;

Hasil praktik shalat siswa pada siklus II dapat dilihat pada tabel dan gambar grafik berikut.

Tabel 4. Nilai Praktik sholat wajib Siklus II

\begin{tabular}{|c|c|c|}
\hline No & Uraian & Nilai Ulangan Harian \\
\hline 1 & Nilai terendah & $\mathbf{7 0}$ \\
\hline 2 & Nilai tertinggi & $\mathbf{1 0 0}$ \\
\hline 3 & Nilai rerata & $\mathbf{8 5 , 0}$ \\
\hline 4 & Rentang nilai & $\mathbf{3 0}$ \\
\hline
\end{tabular}




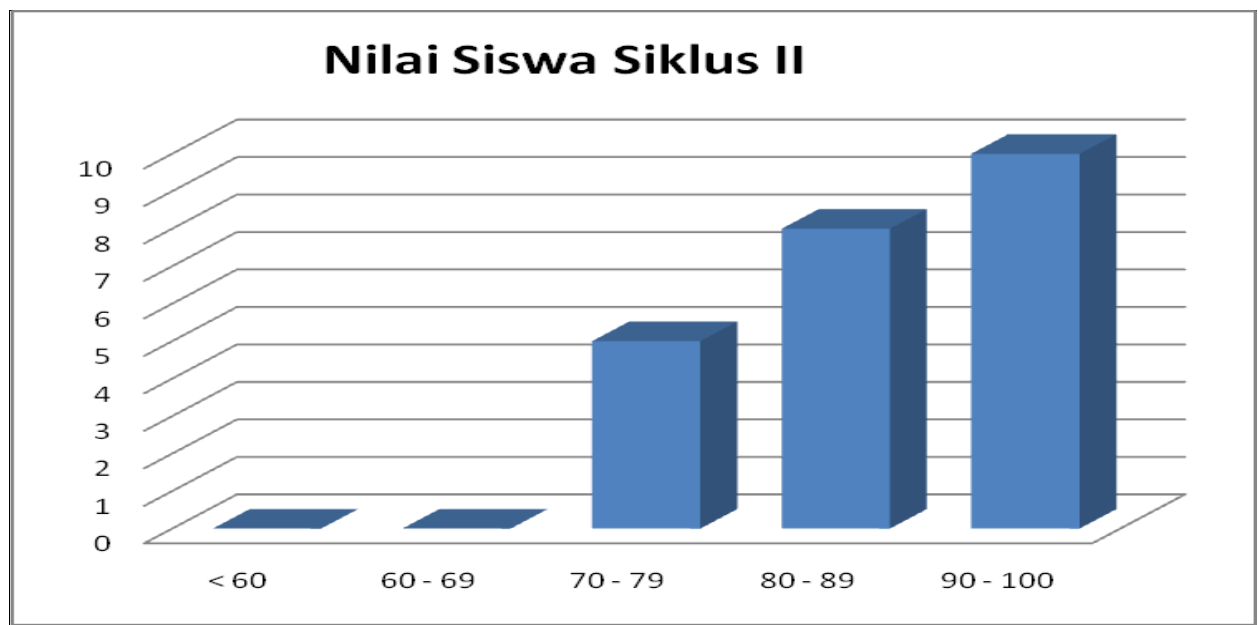

Gambar 5. Grafik Nilai praktik sholat wajib Siklus II

\title{
nilai ketuntasan Siklus II
}

\author{
tuntas belum tuntas
}

$0 \%$

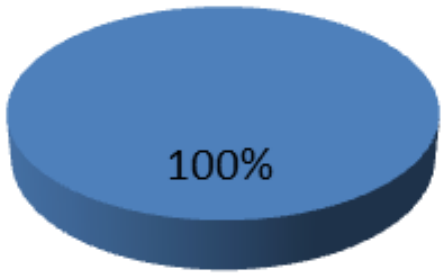

\section{Gambar 6. Grafik Nilai Ketuntasan Belajar Siklus II}

Berdasarkan Tabel dan Gambar grafik diatas diketahui hasil nilai praktik sholat wajib siklus II pada siswa kelas IV SDN Tri Mulya Agungtahun pelajaran 2018/2019 Semua siswa yang berjumlah 23 anak (100\%) dinyatakan tuntas, dengan nilai siswa terendah 70 , nilai tertinggi 100 dan nilai rata kelas 85,0.

\section{Pembahasan}

Hasil pembahasan dalam penelitian ini ada 3 hal, meliputi tindakan, aktivitas, dan kemampuan siswa dalam melakukan sholat wajib.

Tabel 5. Tindakan per Siklus

\begin{tabular}{|c|l|l|l|}
\hline No & \multicolumn{1}{|c|}{ Kondisi Awal } & \multicolumn{1}{|c|}{ Siklus I } & \multicolumn{1}{c|}{ Siklus II } \\
\hline 1 & $\begin{array}{l}\text { Belum } \\
\text { menggunakan } \\
\text { strategi modelling } \\
\text { the way }\end{array}$ & $\begin{array}{l}\text { Menggunakan strategi } \\
\text { modelling the way tanpa } \\
\text { bimbingan guru }\end{array}$ & $\begin{array}{l}\text { Menggunakan strategi } \\
\text { modelling the way dengan } \\
\text { bimbingan guru }\end{array}$ \\
\hline
\end{tabular}

Tabel di atas menunjukkan bahwa pada kondisi awal, pelaksanaan pembelajaran melakukan sholat wajib pada siswa kelas IV SDN Tri Mulya Agung semester genap tahun pelajaran 2018/2019 belum menggunakan strategi modelling the way. Pada siklus I 
menggunakan strategi modelling the way tanpa bimbingan guru. Dilanjutkan siklus II menggunakan strategi modelling the way dengan bimbingan guru. Hal tersebut dimaksudkan untuk mengkombinasikan penggunaan metode agar siswa lebih paham.

Tabel 6. Aktivitas Belajar Siswa per Siklus

\begin{tabular}{|c|c|c|c|c|}
\hline No & $\begin{array}{c}\text { Kondisi } \\
\text { Awal }\end{array}$ & Siklus I & Siklus II & Refleksi \\
\hline 1 & $\begin{array}{l}\text { Siswa: } \\
\text { Aktivitas dan } \\
\text { kemampuan } \\
\text { melakukan } \\
\text { sholat wajib } \\
\text { siswa masih } \\
\text { kurang. }\end{array}$ & $\begin{array}{l}\text { Melafalkan bacaan- } \\
\text { bacaan sholat wajib: } \\
\text { Nilai rata-rata: } 3,4 \\
\text { Persentase: } 67,8 \% \\
\text { Kategori:baik } \\
\text { Mempraktikkan } \\
\text { gerakan-gerakan } \\
\text { sholat wajib: } \\
\text { Nilai rata-rata 3,7 } \\
\text { Persentase: } 73,9 \% \\
\text { Kategori:baik } \\
\\
\text { Mempraktikkan } \\
\text { keserasian antara } \\
\text { bacaan dan gerakan } \\
\text { sholat wajib: } \\
\text { Nilai rata-rata } 3,6 \\
\text { Persentase: } 71,3 \% \\
\text { Kategori:baik } \\
\text { Praktek sholat: } \\
\text { Nilai rata-rata: } 3,4 \\
\text { Persentase; } 67,8 \% \\
\text { Kategori:baik }\end{array}$ & $\begin{array}{l}\text { Melafalkan bacaan- } \\
\text { bacaan sholat wajib: } \\
\text { Nilai rata-rata: } 4,5 \\
\text { Persentase: } 89,6 \% \\
\text { Kategori: amat baik } \\
\text { Mempraktikkan } \\
\text { gerakan-gerakan } \\
\text { sholat wajib: } \\
\text { Nilai rata-rata } 4,4 \\
\text { Persentase: } 88,7 \% \\
\text { Kategori: amat baik } \\
\\
\text { Mempraktikkan } \\
\text { keserasian antara } \\
\text { bacaan dan gerakan } \\
\text { Sholat wajib: } \\
\text { Nilai rata-rata } 4,3 \\
\text { Persentase: } 87,0 \% \\
\text { Kategori:amat baik } \\
\text { Praktek sholat: } \\
\text { Nilai rata-rata: } 4,3 \\
\text { Persentase; } 86,1 \% \\
\text { Kategori:amat baik }\end{array}$ & 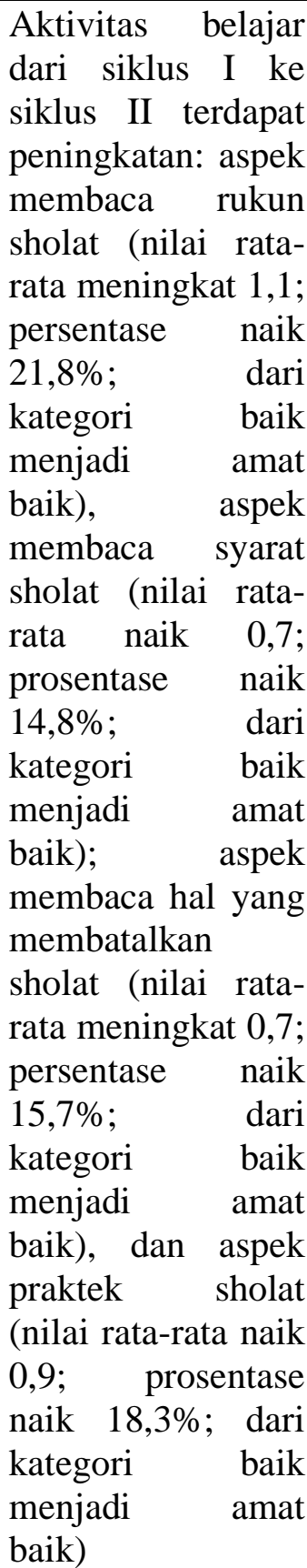 \\
\hline
\end{tabular}

Tabel di atas menunjukkan bahwa dari kondisi awal ke kondisi akhir terdapat peningkatan tentang aktivitas belajar. Aktivitas belajar dari siklus I ke siklus II terdapat peningkatan: melafalkan bacaan-bacaan sholat wajib (nilai rata-rata meningkat 1,1; persentase naik 21,8\%; dari kategori baik menjadi amat baik), aspek mempraktikkan gerakan-gerakan sholat wajib (nilai rata-rata naik 0,7; prosentase naik 14,8\%; dari kategori baik menjadi amat baik); aspek mempraktikkan keserasian antara gerakan dan bacaan sholat wajib (nilai rata-rata meningkat 0,7 ; persentase naik 15,7\%; dari kategori baik menjadi amat baik), dan aspek praktek sholat (nilai rata-rata naik 0,9; prosentase naik 18,3\%; dari kategori baik menjadi amat baik). 


\section{EDUCATOR : Jurnal Inovasi Tenaga Pendidik dan Kependidikan Vol. 1 No. 2 Desember 2021, e-ISSN : 2807-8659 | p-ISSN : 2807-8829}

Berdasarkan hasil penelitian yang dilakukan oleh Anegiwati (2016), menjelaskan bahwa pelaksanaan penelitian dengan penerapan strategi modelling the way dapat meningkatkan hasil belajar PAI Siswa mulai dari siklus I sampai siklus II. Berdasarkan hasil pengamatan yang dilakukan terhadap aktivitas yang dilakukan guru pada siklus I dan siklus II dapat dijelaskan sebagai berikut: a) Guru mengidentifikasi beberapa situasi umum dan siswa dituntut untuk menggunakan keterampilan yang baru dibahas, secara umum guru telah melakukannya dengan sempurna sesuai dengan RRP yang disusun sebelumnya. Berdasarkan analisis peneliti aktivitas yang dilakukan guru selama prosess pembelajaran dengan penerapan strategi modelling the way khusunya mengidentifikasi beberapa situasi umum telah berjalan dengan baik sesuai dengan yang tertuang dalam RPP yang disusun sebelumnya. b) Guru membagi kelas ke dalam beberapa kelompok kecil menurut jumlah siswa yang diperlukan untuk mendemonstrasikan satu skenario (minimal 2 atau 3 orang) secara umum guru telah melakukannya dengan sempurna sesuai dengan RRP yang disusun sebelumnya. c) Guru memberi waktu sepuluh atau sampai 15 menit untuk menciptakan skenario kepada setiap kelomok siswa pada pertemuan pertama dan kedua belum dilakukan guru dengan baik namun pada pertemuan ke 3 dan 4 telah dilakukan guru dengan baik dan sempurna. Berdasarkan analisis peneliti aktivitas pada pertemuan pertama dan kedua kurang berjalan dengan baik disebabkan oleh guru belum begitu hafal dengan langkahlangkah pembelajaran yang disusun dengan penerapan strategi modelling the way. d) Guru memberi waktu sampai 7 menit untuk berlatih pada pertemuan pertama telah dilakukan guru namun pada pertemuan ke 2 guru tidak melakukannya namun pada pertemuan ke 3 dan 4 telah dilakukan guru dengan baik dan sempurna. Berdasarkan analisis peneliti aktivitas pada pertemuan pertama dan kedua kurang berjalan dengan baik khususnyan dalam memberi waktu sampai 7 menit untuk berlatih disebabkan oleh guru belum begitu hafal dengan langkah-langkah pembelajaran. e) Guru memberi kesempatan untuk memberikan feedback pada setiap demonstrasi yang dilakukan pada pertemuan ke 1 dan 2 guru belum melaksanakannya. Begitu pula pada pertemuan ke 3 juga guru tidak malakukannya dan setelah pertemuan ke 4 guru melaksanakannya dengan baik dan sempurna.

Pada penelitian yang dilakukan oleh Musyawwarotul (2015) diungkapkan bagaimana penerapan pembelajaran metode Modelling The Way berpengaruh terhadap penyerapan siswa selama proses pembelajaran berlangsung. Dalam hal ini pengukuran hasil belajar dilakukan meliputi 3 penilaian yaitu : Diskusi kelompok, Performance /praktek sholat, Tes Tulis.

Pada siklus II dari penelitiannya menunjukkan bahwa metode modelling the way memiliki dampak positif terhadap peningkatan hasil belajar siswa kelas II MI Ma'arif At-Taqwa Lamongan. Hal ini dapat dilihat dari semakin meningkatnya hasil belajar Fiqih terhadap materi yang disampaikan oleh guru selama ini. Ketuntasan meningkat dari siklus I dan II. Didapatkan hasil sebagai berikut:

1. Pada penilaian diskusi kelompok yang terdapat 25 siswa $(80,64 \%)$ yang aktif saat berdiskusi sedangkan hanya 6 siswa $(19,35 \%)$ yang masih tidak terlihat aktif.

2. Pada penilaian Performance / praktek sholat yang dianggap sudah sempurna saat melaksanakan sholat terdapat 26 siswa $(83,87 \%)$ dan 5 siswa $(16,12 \%)$ yang masih butuh bimbingan orang tua dirumah.

3. Pada penilaian tes tulis untuk mengukur pemahaman siswa terdapat 24 siswa $(77,41 \%)$ terdapat banyak peningkatan pemahaman tentang materi

Dengan demikian, pengaplikasikan metode pembelajaran Modelling The Way dapat membantu tercapainya peningkatan hasil belajar siswa pada materi tata cara sholat berjamaah

\section{KESIMPULAN}

Berdasarkan hasil penelitian dapat disimpulkan bahwa melalui strategi modelling the way dapat meningkatkan aktivitas dan kemampuan melakukan sholat wajib pada siswa Kelas IV SDN Tri Mulya Agung Semester genap tahun pelajaran 2018/2019. Aktivitas belajar dari siklus I ke siklus II terdapat peningkatan: aspek melafalkan bacaan-bacaan sholat wajib (nilai rata-rata meningkat 1,1 ; persentase naik $21,8 \%$; dari kategori baik menjadi amat baik), aspek 
mempraktikkan gerakan-gerakan sholat wajib (nilai rata-rata naik 0,7; prosentase naik 14,8\%; dari kategori baik menjadi amat baik); aspek keserasian antara bacaan-dan gerakan sholat wajib (nilai rata-rata meningkat 0,7 ; persentase naik 15,7\%; dari kategori baik menjadi amat baik), dan aspek praktek sholat (nilai rata-rata naik 0,9; prosentase naik 18,3\%; dari kategori baik menjadi amat baik). Hasil belajar siswa dari kondisi awal ke siklus II mengalami peningkatan, yaitu dari 7 siswa (30\%) yang mendapat nilai tuntas menjadi 23 siswa (100\%). Terjadi peningkatan sebanyak 16 siswa (70\%) dan nilai rata-rata kelas dari 60,2 menjadi 85,0, meningkat sebesar 24,8.

\section{DAFTAR PUSTAKA}

Al Qur'an dan Terjemah. (2000). Jakarata: CV. Pustaka Al-Kautsar.

Anegawati, Euis. (2016). Penerapan Strategi Pembelajaran Modelling The Yay Dapat Meningkatkan Hasil Belajar Pendidikan Agama Islam (PAI) Siswa Kelas IV SD Negeri 010 Banjar Panjang Kecamatan Kerumutan. Jurnal Primary Program Studi Pendidikan Guru Sekolah Dasar Fakultas Keguruan dan Ilmu Pendidikan Universitas Riau, Volume 5, Nomor 3. Edisi Khusus HUT PGRI Ke-71

Arikunto, Suharsimi. (2015). Penelitian Tindakan Kelas. Jakarta: PT. Bumi Aksara

Djamarah. (2006). Strategi Belajar Mengajar. Jakarta. Rineka Cipta

Ghazaly, Faesal. (2016). Pendidikan Agama Islam dan Budi Pekerti Kelas IV. Jakarta: Kementerian Pendidikan dan Kebudayaan

Musyawwarotul Ilmiyah. (2015). Penerapan metode Modelling The Way untuk meningkatkan hasil belajar fiqih materi tata cara sholat berjama'ah pada siswa kelas II MI Ma'arif At-Taqwa Lamongan. Skripsi. Surabaya: Jurusan pendidikan guru madrasah ibtidaiyah UIN Sunan Ampel.

Zaini, Hisyam. (2008). Strategi Pembelajaran Aktif. Yogyakarta: Pustaka Insan Madani 